XLI Reunião Anual da Sociedade Brasileira de Bioquímica e Biologia Molecular - SBBq

Foz do Iguaçu, PR, Brasil - 19 a 22 de maio de 2012

\title{
The Web Portal Química Nova Interativa: a well Successful Model for Science Diffusion
}

\section{Guilherme Andrade Marson}

Department of Chemistry, Institute of Chemistry, University of São Paulo Paulo, São Paulo, Brazil

The growing disinterest of younglings for science is translated into the lack of professionals in several fields: 2000 professionals are needed in the base chemical industry; 5000 positions of science teacher remain unfilled in the educational system; millions of $\mathrm{PhD}$ must be issued to fuel the expansion of the higher education system. These and other questions motivated several actions for divulging chemistry in 2011, International Year of Chemistry (IYC). Positive results arising from the articulation of the web portal Química Nova Interativa (http://anint.sbq.org.br) will be presented. Surpassing the million-access mark, the QNint portal delivers revised material, including a unique library of more than 300 interactive 3D molecules. In the YIC, the QNint portal hosted the Brazilian web site of the Global Water Experiment (IUPAC major global action in the YIC). This action entailed countrywide distribution of thousand of $\mathrm{pH}$ measurements kits and yielded more than 2500 experimental data entries from schools in almost every Brazilian state. This partnership is a well-succeeded model of interaction for the scientific community, the government and society: I - it aggregates members from universities, scientific societies and the educational system; II - it extrapolates the one-way provisional role commonly given to information technologies; III - it fosters continent-wide actions involving heterogeneous participants; IV - it facilitates data acquisition for evaluating such actions. 
This document was created with Win2PDF available at http://www.win2pdf.com. The unregistered version of Win2PDF is for evaluation or non-commercial use only. This page will not be added after purchasing Win2PDF. 